\title{
Assessment of Executive Function in Patients with Traumatic Brain Injury with the Wisconsin Card-Sorting Test
}

\section{Lizzette Gómez-de-Regil 1}

Hospital Regional de Alta Especialidad de la Península de Yucatán Calle 7, No. 433 por 20 y 22, Fraccionamiento Altabrisa Mérida, Yucatán 97130, Mexico; gomezderegil@gmail.com; Tel.: +52-(999)-942-7600; Fax: +52-(999)-254-3535

Received: 20 August 2020; Accepted: 24 August 2020; Published: 1 October 2020

\begin{abstract}
This review aimed at providing a brief and comprehensive summary of recent research regarding the use of the Wisconsin Card-Sorting Test (WCST) to assess executive function in patients with traumatic brain injury (TBI). A bibliographical search, performed in PubMed, Web of Science, Scopus, Cochrane Library, and PsycInfo, targeted publications from 2010 to 2020, in English or Spanish. Information regarding the studies' designs, sample features and use of the WCST scores was recorded. An initial search eliciting 387 citations was reduced to 47 relevant papers. The highest proportion of publications came from the United States of America (34.0\%) and included adult patients (95.7\%). Observational designs were the most frequent (85.1\%), the highest proportion being cross-sectional or case series studies. The average time after the occurrence of the TBI ranged from 4 to 62 years in single case studies, and from 6 weeks up to 23.5 years in the studies with more than one patient. Four studies compared groups of patients with TBI according to the severity (mild, moderate and/or severe), and in two cases, the studies compared TBI patients with healthy controls. Randomized control trials were seven in total. The noncomputerized WCST version including 128 cards was the most frequently used $(78.7 \%)$. Characterization of the clinical profile of participants was the most frequent purpose $(34.0 \%)$. The WCST is a common measure of executive function in patients with TBI. Although shorter and/or computerized versions are available, the original WCST with 128 cards is still used most often. The WCST is a useful tool for research and clinical purposes, yet a common practice is to report only one or a few of the possible scores, which prevents further valid comparisons across studies. Results might be useful to professionals in the clinical and research fields to guide them in assessment planning and proper interpretation of the WCST scores.
\end{abstract}

Keywords: executive function; traumatic brain injury; Wisconsin Card-Sorting Test

\section{Introduction}

Traumatic brain injury (TBI) is an alteration in normal brain function or any other evidence of brain pathology caused by an impact from external mechanical forces, such as rapid acceleration or deceleration, a bump or jolt to the head or penetration by a projectile. About sixty-nine million people experience TBI from all causes each year, with the Southeast Asian and Western Pacific regions experiencing the greatest overall burden of disease [1]. TBI is mild, moderate or severe, depending on the resulting severity and duration of loss of consciousness, post-traumatic amnesia and neuro-radiological evidence of cerebral damage. This classification system is highly reliable for first diagnosis; however, its prognostic value for long-term neuropsychological outcome is still limited as it rarely takes into account premorbid factors, underlying structural damage and the impact of non-neurological factors [2]. 
The main outcomes following TBI include mortality, functional disability, health-related quality of life, and cognitive, psychiatric and social complications [3]. Anatomically, frontal lobes are particularly vulnerable to TBI, given their site at the front of the brain and their large size and because of scraping of the orbitofrontal region against the fosse. Damage to the prefrontal cortex is highly, although not exclusively, associated with impairment of executive function, a complex set of abilities that include various skills such as working memory, initiating or inhibiting behavior, cognitive flexibility and decision-making, as well as planning and organization, monitoring performance, problem-solving, metacognition, learning rules, controlling emotions, multitasking, self-awareness, social behavior and motivation [4-6]. Patients with TBI may experience only some of these difficulties, and further, these difficulties might be almost imperceptible. Unawareness of executive dysfunction is common in patients with TBI, and signals might be only noticeable to those people in close and frequent interaction with the patient. On the other hand, other symptoms might be so intrusive that they can affect negatively the patient's daily activities, emotional wellbeing and social interactions.

Neuropsychological assessment of TBI often occurs during inpatient hospitalization if post-traumatic amnesia has resolved [7]. Executive dysfunction, especially if mild, might not be noticeable immediately after experiencing a TBI, but rather manifest later on when the individual starts reintegration to his/her usual activities. Among various tests to assess executive function, the Wisconsin Card-Sorting Test (WCST) is one of the most widely known and used in clinical and research practice. Laxe and colleagues, in a systematic review of scales used in TBI patients, found that $15 \%$ of 193 selected research articles included the WCST [8] as a measure.

Grant and Berg developed the WCST in 1948, but it was not until 1963 that Milner introduced it as a tool to assess prefrontal lobe dysfunction in patients with brain lesions. The original WCST presents 4 key cards and 128 response cards with geometric figures (e.g., squares, triangles, circles and stars) varying according to color, form or number. A shorter version, the WCST-64, includes only 64 cards. The interviewer presents the stimulus cards one by one, and the person must select a card matching the stimulus according to a criterion in turn. The matching criterion can be a color, figure or number. After each matching, the interviewer tells the interviewee if the answer was correct or not, and learning must follow through trial and error. The classification criterion changes after the interviewee yields 10 consecutive correct matches without warning, demanding a flexible cognitive shift. There is no time limit and the test finishes when the individual sorts all the cards or if he/she achieves six correct sorting criteria. Once completed, the total and percentage of the following scores are calculated: number of errors, perseverative responses, perseverative errors, nonperseverative errors and conceptual level responses. The manual provides tables, according to age and/or years of education, to convert raw scores into standard scores, $\mathrm{T}$ scores and percentile scores. Additionally, the number of categories completed, trials to complete first category, failure to maintain set (when an error follows five or more correct consecutive answers) and learning to learn scores can be calculated and transformed into percentiles. From these various scores, the numbers of perseverative errors, nonperseverative errors and categories completed are the most commonly used for reporting the patient's performance (see [9] for a review and update).

Frontal lobes, responsible for the executive function, are likely to be damaged after TBI. Executive function plays a significant role in the daily performance of the person, and due to its close connection to other cognitive functions, reliable measures of executive function are of importance for clinical and research purposes. Although not the only one, the WCST is one of the most widely known and used instruments to assess executive function in a variety of clinical populations with brain dysfunctions. Nevertheless, and to the best knowledge of the author, no publication is yet available that summarizes research using this tool in patients with TBI. This information, properly organized, might be useful to professionals in the clinical and research fields to guide them in assessment planning and proper interpretation of results. This review aims at providing a brief and comprehensive summary of recent research making use of the WCST to assess executive function in patients with TBI. 


\section{Methods}

The author performed a bibliographical search in the PubMed, Web of Science, Scopus, Cochrane Library and PsycInfo databases. The terms "traumatic brain injury" and "TBI" were entered along with "Wisconsin card-sorting test" and "WCST". Inclusion criteria were: (1) research papers, (2) published in peer-reviewed journals, (3) published during the last decade (2010 to May 2020) and (4) available in English or Spanish. Exclusion criteria were: (1) not original research (e.g., letters, dissertations, reviews and/or meta-analyses) and (2) content not related to the objective of the study (i.e., study design not including patients with TBI and/or not using the WCST). The author accessed the online resources on 20 May 2020. After applying the inclusion and exclusion criteria, a final list of references was generated and the full content of the manuscripts was consulted to verify their relevance to the objectives of the review. Through complete and thorough readings of the manuscripts, the following data were collected: year of publication, research team setting, participant age stage (pediatric or adult) and study design. Regarding participants, the sample size, age, gender, severity of TBI and time since TBI were recorded. Concerning the WCST, the version used and reported scores were registered, along with its use in the study.

\section{Results}

An initial search produced 387 results from the five sources, which was reduced to 186 by filtering duplicated results. After applying the exclusion criteria and reviewing abstracts and/or manuscripts, the list was reduced to 47 relevant publications (Figure 1).

Table 1 summarizes the basic features of the publications. The highest proportion of publications came from the United States of America (34.0\%), followed by Italy $(14.9 \%$ ) and other countries worldwide $(51.1 \%)$. Regardless of the language spoken in the setting of research, all publications provided an abstract written in English, yet two manuscripts were in Spanish. The highest proportion of publications $(n=20)$ came from settings whose official language is English (United States of America, Canada and Australia), and the remainder $(n=27)$ came from countries with diverse languages, such as Italian, Spanish, Portuguese, French, Hebrew, Japanese, Korean, Malay, Serbian and Thai. Most studies included adult samples (95.7\%), and only two (4.3\%) had pediatric samples.

Table 1. Basic features of publications $(n=47)$.

\begin{tabular}{cccccc}
\hline \multicolumn{5}{c}{ Year of Publication: $\boldsymbol{n} \mathbf{( \% )}$} \\
\hline $2010:$ & $5(10.6)$ & $2011:$ & $9(19.1)$ & $2012:$ & $6(12.8)$ \\
$2013:$ & $5(10.6)$ & $2014:$ & $5(10.6)$ & $2015:$ & $4(8.5)$ \\
$2016:$ & $4(8.5)$ & $2017:$ & $3(6.4)$ & $2018:$ & $2(4.3)$ \\
$2019:$ & $3(6.4)$ & $2020:$ & $1(2.1)$ & & \\
& & & Location: $\boldsymbol{n}(\mathbf{\%})$ & Serbia & $1(2.1)$ \\
Australia & $2(4.3)$ & India & $2(4.3)$ & South Africa & $1(2.1)$ \\
Brazil & $3(6.4)$ & Italy & $7(14.9)$ & Spain & $2(4.3)$ \\
Canada & $2(4.3)$ & Israel & $2(4.3)$ & Thailand & $1(2.1)$ \\
China & $2(4.3)$ & Japan & $1(2.1)$ & United States of America & $16(34.0)$ \\
Colombia & $1(2.1)$ & Korea & $1(2.1)$ & & \\
France & $2(4.3)$ & Malaysia & $1(2.1)$ & \multicolumn{5}{c}{}
\end{tabular}

Table 2 summarizes information about the design of the studies with the corresponding references. Observational (descriptive) designs were the most frequent (85.1\%), particularly cross-sectional and case series studies. There were seven randomized control trials. The original WCST version, comprising 128 cards and applied by an interviewer, was the most frequently used version (78.7\%). Only three studies (5.4\%) made use of computerized versions. Regarding WCST scores, perseverative errors $(46.8 \%)$ followed by categories completed (42.6\%) and perseverative responses (31.9\%) stood out as the most often reported. In the selected studies, the use of the WCST was diverse. Characterization of the clinical profile of participants was the most frequent purpose (34.0\%), in accordance with the high 
percentage of observational studies. In some cases (38.3\%), WCST scores aimed at detecting differences in the executive function performance of TBI patients in comparison to clinical groups or healthy controls, or between groups of TBI patients defined by a selected clinical criterion (e.g., self-awareness, history of suicide attempt, anosmia).

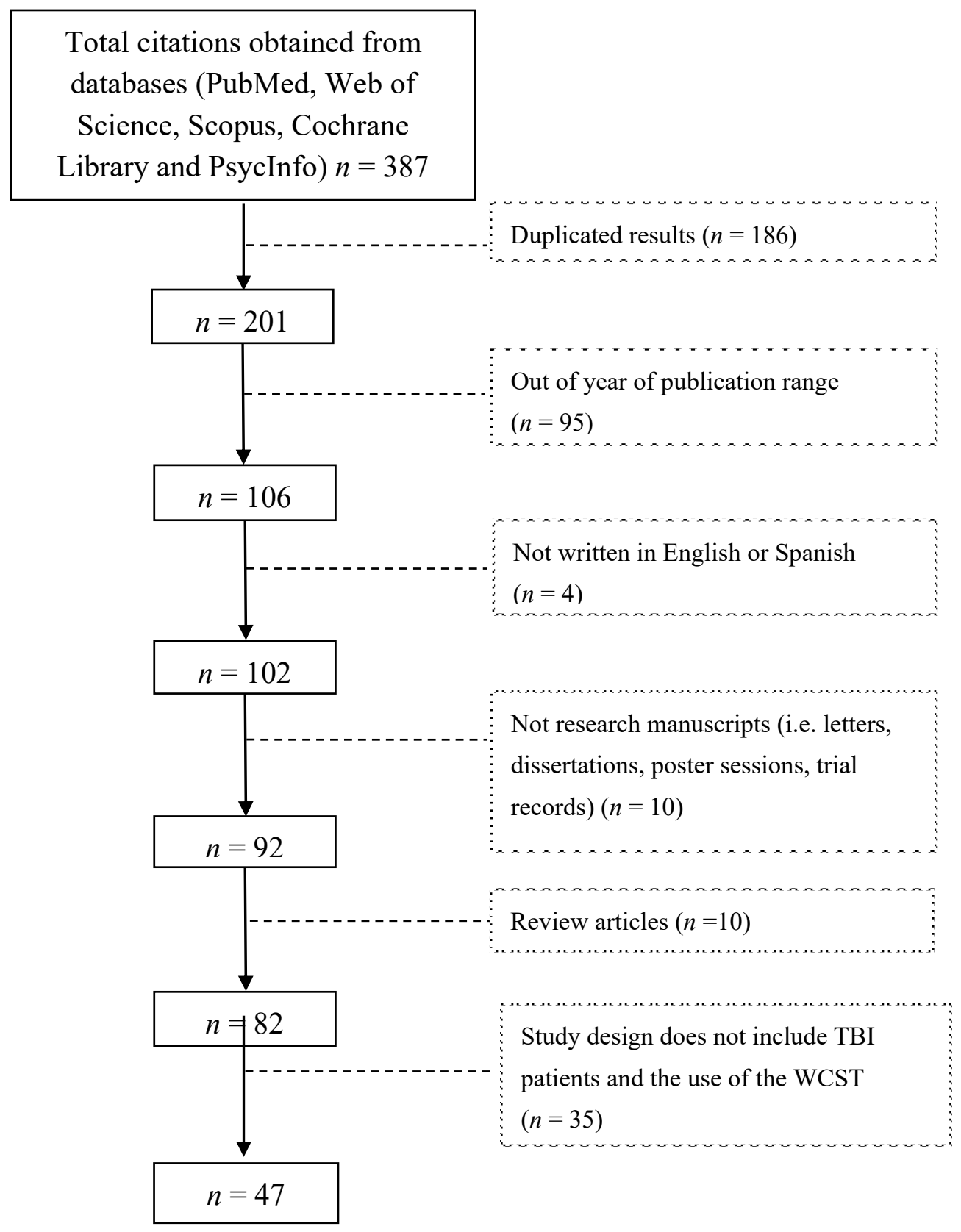

Figure 1. Study flow diagram.

Regarding the characteristics of the TBI patients participating in the studies, in some cases, samples included mostly $(57.4 \%)$ or only $(6.4 \%)$ men, and others included mostly $(8.5 \%)$ or only $(10.6 \%)$ women. Sex was not reported in eight (17.0\%) manuscripts. Mean age in pediatric samples ranged from 14 to 15 years and from 20 to 77 in adult samples. The average time after the occurrence of the TBI, as reported in 34 manuscripts, ranged from 4 to 62 years in single case studies, and from 6 weeks up to 23.5 years in the studies with more than one patient. Although not stated, the time intervals suggest that all patients had passed the acute phase. Severity of the TBI in participants was reported in 37 manuscripts. Most studies (23.4\%) included patients with a mild to severe TBI, followed by 
samples with moderate to severe TBI (12.8\%) and mild to moderate TBI (10.6\%). Some studies included exclusively patients with mild $(14.9 \%)$, moderate $(2.1 \%)$ or severe $(14.9 \%)$ TBI.

A total of 32 studies exclusively included patients with TBI: six single cases, 11 analyzing all participants as a single group, eight grouping participants according to some clinical feature (e.g., severity of TBI, disability, history of suicide attempt, anosmia) and seven randomized control trials comparing groups by treatment (e.g., cognitive rehabilitation, growth hormone replacement therapy, sertraline medication, neuro-feedback training). On the other hand, 15 studies included not only TBI patients but also healthy controls $(n=12)$, clinical controls $(n=2)$ or both a healthy control group and clinical control group $(n=1)$. Only four studies compared the performance of patients according to severity (mild, moderate and/or severe); two of them also including a healthy control group. Most studies (72.3\%) used the WCST scores as a descriptive feature of participants, comparing between groups or not. Table 3 presents the results and references.

Table 2. Study design features of publications $(n=47)$.

\begin{tabular}{|c|c|c|}
\hline \multicolumn{2}{|c|}{ Study Design: $n(\%)$} & References \\
\hline \multicolumn{3}{|c|}{ Observational } \\
\hline Case report & $6(12.8)$ & [10-15] \\
\hline Case series & $10(21.3)$ & [16-25] \\
\hline Cohort & $1(2.1)$ & [26] \\
\hline Cross-sectional one group & $10(21.3)$ & [27-36] \\
\hline Cross-sectional two or more groups & $13(27.7)$ & [37-49] \\
\hline \multicolumn{3}{|l|}{ Experimental } \\
\hline Randomized control trial & $7(14.9)$ & [50-56] \\
\hline \multicolumn{2}{|c|}{ WCST version: $n(\%)$} & References \\
\hline \multicolumn{3}{|c|}{ With interviewer } \\
\hline WCST-128 & $37(78.7)$ & {$[10-21,24,25,27-29,31-40,42,43,45-49,52,55,56]$} \\
\hline WCST-64 & $6(12.8)$ & {$[26,30,41,50,51,54]$} \\
\hline WCST-48 & $1(2.1)$ & [44] \\
\hline \multicolumn{3}{|c|}{ Computerized } \\
\hline WCST-128 & $2(4.3)$ & {$[23,53]$} \\
\hline WCST-64 & $1(2.1)$ & {$[22]$} \\
\hline \multicolumn{2}{|c|}{ WCST reported scores: $n(\%)$} & References \\
\hline Correct responses & $5(10.6)$ & {$[16,23,26,37,52]$} \\
\hline Errors & $13(27.7)$ & {$[10,15,16,19,23,31,34,37,41,42,44,46,56]$} \\
\hline Perseverative responses & $15(31.9)$ & {$[10,16,17,20,23,30-32,34,36-38,42,45,55]$} \\
\hline Perseverative errors & $22(46.8)$ & {$[14-16,23-28,31,33,37,39,41,44,45,47,49-51,54,56]$} \\
\hline Nonperseverative errors & $11(23.4)$ & {$[15,16,23,28,31,37,39,42,44,45,49]$} \\
\hline Conceptual-level responses & $9(19.1)$ & {$[10,15,16,31,34,42,54-56]$} \\
\hline Categories completed & $20(42.6)$ & {$[14-17,20,23,24,31-34,36,37,41-46,49]$} \\
\hline Trials to complete first category & $6(12.8)$ & {$[16,23,34,42,43,46]$} \\
\hline Failure to maintain set & $5(10.6)$ & {$[31,34,42,46,47]$} \\
\hline Learning to learn & $0(0)$ & \\
\hline \multicolumn{2}{|c|}{ Use of WCST scores in the study: $n(\%)$} & References \\
\hline $\begin{array}{c}\text { Description of clinical profile of } \\
\text { participants }\end{array}$ & $16(34.0)$ & {$[10,12-17,19-22,24,25,27,28,37]$} \\
\hline $\begin{array}{c}\text { Comparison of clinical profile within } \\
\text { groups }\end{array}$ & $18(38.3)$ & {$[29,31-36,39-49]$} \\
\hline Treatment outcome & $7(14.9)$ & {$[26,50-52,54-56]$} \\
\hline Predictor variable & $4(8.5)$ & {$[11,18,30,38]$} \\
\hline Predicted outcome & $1(2.1)$ & [23] \\
\hline Inclusion criterion & $1(2.1)$ & [53] \\
\hline
\end{tabular}

Additionally, in an effort to offer an overview of the performances across studies, the author selected the ones using the 128-card version, the most often used, and reporting perseverative errors and/or completed categories scores, which were the most often available. Table 4 summarizes the results. Compared to healthy controls, TBI patients produced more perseverative errors, as did those with a severe TBI in comparison to those with a moderate or mild TBI. Given the differences across samples and the type of reported scores, further analyses were not possible. Regarding the number of completed categories (possible range: 0 to 6), in a couple of studies, participants scored the highest, while most scores ranged from 4 to 5 . In addition, some scores from patients with TBI were not so distant from those from healthy controls. 
Table 3. Characteristics of samples $(n=47)$.

\begin{tabular}{|c|c|c|c|c|c|}
\hline 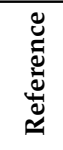 & $\%$ of Male Participants & $\begin{array}{l}\text { Mean Age (Years) of } \\
\text { Patients with TBI }\end{array}$ & Mean Time after Injury & Severity of TBI & Participants \\
\hline [10] & 0 & 77 & NR & NR & $\begin{array}{c}1 \text { TBI patient } \\
1 \text { healthy control }\end{array}$ \\
\hline [11] & 78 & 36.26 & 11.20 months & NR & 80 TBI patients \\
\hline [12] & 100 & 45 & NR & mild & 1 TBI patient \\
\hline [13] & 100 & 21 & 4 years & NR & 1 TBI patient \\
\hline [14] & 0 & 67 & 62 years & NR & 1 TBI patient \\
\hline [15] & 0 & 20 & 8 years & severe & 1 TBI patient \\
\hline [16] & 76 & 34 & NR & mild to severe & 30 TBI patients \\
\hline [17] & 75 & 30.73 & 7.04 months & moderate to severe & 32 TBI patients \\
\hline [18] & 45 & NR & 78 of days (median) & NR & 69 TBI patients \\
\hline [19] & 0 & 22 & 10 years & severe & 1 TBI patient \\
\hline [20] & 68 & 15.1 & 23.0 months & NR & 65 TBI patients \\
\hline [21] & 35 & 34.5 & 1671.3 days & mild to severe & 19 TBI patients \\
\hline [22] & 87 & 35.52 & NR & NR & 94 TBI patients \\
\hline [23] & NR & 43.68 & 103 months & severe & 25 TBI patients \\
\hline [24] & 74 & 32 & 8.7 months & moderate to severe & 43 TBI patients \\
\hline [25] & 100 & 35.3 & 6.6 years & mild & 56 TBI patients \\
\hline [26] & 95 & 25.79 & 6 weeks & mild to moderate & $\begin{array}{c}19 \text { TBI patients } \\
14 \text { healthy controls }\end{array}$ \\
\hline [27] & 80 & 29.5 & NR & mild & $\begin{array}{c}60 \text { TBI patients } \\
32 \text { healthy controls }\end{array}$ \\
\hline [28] & NR & 35.4 & 39.1 months & mild & $\begin{array}{l}10 \text { nonaphasic speaker TBI patients } \\
13 \text { neurologically intact controls }\end{array}$ \\
\hline [29] & 57 & 32 & 25 months & mild to severe & $\begin{array}{c}7 \text { TBI patients } \\
7 \text { patients with right brain damage }\end{array}$ \\
\hline [30] & 82 & 37.3 & NR & mild to severe & 377 TBI patients \\
\hline [31] & 90 & 30.3 & 2.13 months & mild & $\begin{array}{c}30 \text { TBI patients } \\
30 \text { healthy controls }\end{array}$ \\
\hline
\end{tabular}


Table 3. Cont

\begin{tabular}{|c|c|c|c|c|c|}
\hline 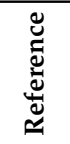 & $\%$ of Male Participants & $\begin{array}{l}\text { Mean Age (Years) of } \\
\text { Patients with TBI }\end{array}$ & Mean Time after Injury & Severity of TBI & Participants \\
\hline [32] & 91 & 33.6 & 6.72 years & severe & $\begin{array}{c}11 \text { TBI patients } \\
11 \text { healthy controls }\end{array}$ \\
\hline [33] & NR & 36.18 & 48.6 months & moderate to severe & $\begin{array}{l}20 \text { severe TBI patients } \\
20 \text { moderate TBI patients } \\
20 \text { healthy controls }\end{array}$ \\
\hline [34] & 69 & 25.53 & 8.6 months & severe & $\begin{array}{l}29 \text { TBI patients } \\
38 \text { healthy controls }\end{array}$ \\
\hline [35] & 85 & 40.5 & 335 days (median) & mild to severe & $\begin{array}{c}27 \text { TBI patients } \\
18 \text { healthy controls }\end{array}$ \\
\hline [36] & 80 & 36.9 & 262 days & severe & $\begin{array}{c}20 \text { TBI patients with adequate levels of } \\
\text { self-awareness } \\
20 \text { healthy controls }\end{array}$ \\
\hline [37] & 0 & 14.0 & $\begin{array}{l}<6 \text { months, } 7 \text { patients } \\
\geq 6 \text { months and }<12 \\
\text { months, } 3 \text { patients } \\
\geq 12 \text { months, } 10 \text { patients }\end{array}$ & NR & $\begin{array}{l}20 \text { TBI patients } \\
7 \text { healthy controls }\end{array}$ \\
\hline [38] & 45 & 44.55 & NR & mild & $\begin{array}{l}95 \text { TBI patients who passed the } \\
\text { performance validity measures } \\
60 \text { TBI patients who failed the } \\
\text { performance validity measures }\end{array}$ \\
\hline [42] & 75 & 37.6 & 37.7 months & mild to severe & $\begin{array}{c}176 \text { TBI patients } \\
49 \text { patients with diffuse neurological } \\
\text { impairment } \\
20 \text { healthy controls }\end{array}$ \\
\hline [43] & 51 & 51.25 & NR & moderate to severe & $\begin{array}{c}73 \text { TBI patients } \\
60 \text { patients with no TBI }\end{array}$ \\
\hline [44] & 77 & 36.56 & 22 months & mild to severe & $\begin{array}{l}39 \text { mild TBI patients } \\
57 \text { severe TBI patients }\end{array}$ \\
\hline [45] & 85 & 30.6 & $\begin{array}{c}0.9 \text { years median } \\
\text { interval }\end{array}$ & severe & $\begin{array}{l}29 \text { TBI patients with good metacognitive } \\
\text { self-awareness } \\
23 \text { TBI patients with heightened } \\
\text { metacognitive self-awareness }\end{array}$ \\
\hline
\end{tabular}


Table 3. Cont

\begin{tabular}{|c|c|c|c|c|c|}
\hline 芯 & $\%$ of Male Participants & $\begin{array}{l}\text { Mean Age (Years) of } \\
\text { Patients with TBI }\end{array}$ & Mean Time after Injury & Severity of TBI & Participants \\
\hline [46] & NR & 40.97 & 954.57 days & mild & $\begin{array}{l}77 \text { TBI patients grouped as disabled or } \\
\text { impaired }\end{array}$ \\
\hline [47] & 94 & 51.2 & 23.5 years & mild to severe & $\begin{array}{l}18 \text { TBI patients with a history of at least } \\
\text { one suicide attempt } \\
29 \text { TBI patients with no history of suicide } \\
\text { attempt }\end{array}$ \\
\hline [48] & 90 & 39.3 & NR & mild to moderate & $\begin{array}{l}9 \text { mild TBI patients } \\
11 \text { moderate TBI patients } \\
27 \text { healthy controls }\end{array}$ \\
\hline [49] & NR & 38.18 & NR & mild to severe & $\begin{array}{l}30 \text { mild TBI patients } \\
30 \text { moderate TBI patients } \\
30 \text { severe TBI patients }\end{array}$ \\
\hline [39] & NR & 36.6 & 22.4 months & moderate & $\begin{array}{c}10 \text { TBI patients } \\
20 \text { healthy controls }\end{array}$ \\
\hline [40] & 67 & 38.8 & 153 months & moderate to severe & $\begin{array}{c}6 \text { planner TBI patients } \\
11 \text { avoider TBI patients }\end{array}$ \\
\hline [41] & 91 & 43.29 & NR & NR & $\begin{array}{l}30 \text { anosmic TBI patients } \\
36 \text { nonanosmic TBI patients }\end{array}$ \\
\hline [50] & 94 & 32 & 4.35 years & mild to moderate & $\begin{array}{l}16 \text { TBI patients treated with supported } \\
\text { employment plus Cognitive Symptom } \\
\text { Management and Rehabilitation Therapy } \\
\text { (CogSMART) } \\
18 \text { TBI patients treated with enhanced } \\
\text { supported employment }\end{array}$ \\
\hline [51] & 96 & 31.76 & 4.56 years & mild to moderate & $\begin{array}{l}25 \text { TBI patients treated with supported } \\
\text { employment plus Cognitive Symptom } \\
\text { Management and Rehabilitation Therapy } \\
\text { (CogSMART) } \\
25 \text { TBI patients treated with enhanced } \\
\text { supported employment }\end{array}$ \\
\hline [52] & NR & 37.6 & 8.05 years & NR & $\begin{array}{l}12 \text { TBI treated with growth hormone } \\
\text { replacement therapy } \\
11 \text { TBI treated with placebo }\end{array}$ \\
\hline
\end{tabular}


Table 3. Cont

\begin{tabular}{|c|c|c|c|c|c|}
\hline 苋 & $\%$ of Male Participants & $\begin{array}{l}\text { Mean Age (Years) of } \\
\text { Patients with TBI }\end{array}$ & Mean Time after Injury & Severity of TBI & Participants \\
\hline [53] & 38 & 45.3 & 12.6 years & mild to severe & $\begin{array}{l}49 \text { TBI patients treated with a } \\
\text { problem-solving and emotional } \\
\text { regulation program } \\
49 \text { TBI patients in waitlist }\end{array}$ \\
\hline [54] & 73 & 34.9 & 20.35 days & moderate to severe & $\begin{array}{c}49 \text { TBI patients treated } \\
\text { with sertraline } 50 \mathrm{mg} \\
50 \text { TBI patients treated with placebo }\end{array}$ \\
\hline [55] & 90 & 29.54 & NR & mild to severe & $\begin{array}{l}30 \text { TBI patients treated with } \\
\text { neuro-feedback training } \\
30 \text { TBI patients in waitlist }\end{array}$ \\
\hline [56] & NR & NR & NR & mild to moderate & $\begin{array}{l}20 \text { TBI patients treated with an artificial } \\
\text { intelligence virtual reality-based } \\
\text { vocational training system } \\
20 \text { TBI patients treated with a } \\
\text { psycho-educational vocational training } \\
\text { program }\end{array}$ \\
\hline
\end{tabular}


Table 4. Mean scores for Perseverative Errors and Categories Completed in Studies Using the WCST-128.

\begin{tabular}{|c|c|c|c|c|c|}
\hline \multicolumn{6}{|c|}{ Perseverative Errors: Number of Incorrect Matches in Sequence, Following the Same Incorrect Criterion } \\
\hline [14] & 6 & [27] & 22.10 (mild TBI) 16.34 (healthy) & [47] & 41.7 (mild to severe TBI) \\
\hline [15] & 79 (severe TBI) & [28] & $\begin{array}{c}8.4 \text { (mild TBI) } \\
0.08 \text { (neurologically intact) }\end{array}$ & [49] & $\begin{array}{c}6.39 \text { (mild TBI) } 26.00 \text { (severe TBI) } \\
18.96 \text { (moderate TBI) }\end{array}$ \\
\hline [16] & $\begin{array}{c}30 \text { (mild TBI) } 30 \text { (severe TBI) } \\
11 \text { (moderate TBI) }\end{array}$ & [31] & $\begin{array}{l}19.76 \text { (mild TBI) } \\
15.67 \text { (healthy) }\end{array}$ & [39] & $\begin{array}{l}6.4 \text { (moderate TBI) } \\
0.5 \text { (healthy) }\end{array}$ \\
\hline [23] & 19.83 (severe TBI) & [33] & $\begin{array}{c}7.40 \text { (moderate TBI) } 0.06 \\
\text { (healthy) } \\
31.67 \text { (severe TBI) }\end{array}$ & [56] & $\begin{array}{l}31.32 \text { virtual reality group at baseline } \\
31.60 \text { psychoeducation group at } \\
\text { baseline }\end{array}$ \\
\hline [24] & 15.6 (moderate to severe TBI) & [37] & 89.42 raw scores & & (mild to moderate TBI) \\
\hline [25] & $10.8($ mild TBI $)$ & [45] & 14.1 (severe TBI) & & \\
\hline \multicolumn{6}{|c|}{ Categories Completed: Number of categories with a sequence of 10 consecutive correct matches } \\
\hline [14] & 6 & [24] & 5 (moderate to severe) & [37] & 4.07 \\
\hline [15] & 6 (severe TBI) & [31] & $\begin{array}{l}4.07 \text { (mild TBI) } \\
4.53 \text { (healthy) }\end{array}$ & [42] & $\begin{array}{c}4.85 \text { controls } \\
\text { 4.90/4.12 (mild TBI, good/poor effort) } \\
\text { 4.57/4.38 (moderate to severe TBI, } \\
\text { good/poor effort) } \\
2.55 \text { diffuse neurological impairment }\end{array}$ \\
\hline [16] & $\begin{array}{c}3 \text { (mild TBI) } 4 \text { (severe TBI) } \\
5 \text { (moderate TBI) }\end{array}$ & [32] & 5.54 (severe TBI) & [43] & $\begin{array}{c}\text { 3.6/3.6 (moderate to severe TBI, } \\
\text { suicide attempt: no/yes) } \\
\text { 3.9/4.1 (healthy, suicide attempt: } \\
\text { no/yes) }\end{array}$ \\
\hline [17] & 4.5 (moderate to severe TBI) & [33] & $\begin{array}{c}5.35 \text { (moderate TBI) } 6.00 \\
\text { (healthy) } \\
3.00 \text { (severe TBI) }\end{array}$ & [45] & 5.1 (severe TBI) \\
\hline [20] & 4.77 & [34] & 5.17(severe TBI) 5.8 (healthy) & [46] & Weighted mean $=0.354($ mild TBI $)$ \\
\hline [23] & 3.04 (severe TBI) & [36] & 4.85 (severe TBI) 5.65 (healthy) & [49] & $\begin{array}{c}4.95 \text { (mild TBI) } 2.50 \text { (severe TBI) } \\
4.00 \text { (moderate TBI) }\end{array}$ \\
\hline
\end{tabular}


Only 12 publications [12,22,25,30,38,41-43,46,47,50,51] reported including effort measures to account for performance/symptom validity. The preferred measures were the Trail Making Test (e.g., total completion time in seconds), the Computerized Assessment Response Bias and the California Verbal Learning Test (e.g., trials 1-5 learning score, long-delay free-recall score).

The author and an invited rater independently assessed the quality of the six randomized control trials with the corresponding Critical Appraisal Skills Programme (CASP) checklist [57] (Table A1 in Appendix A). Interrater reliability by intraclass correlation coefficient (by two-way mixed model and absolute agreement) was $0.70(95 \% \mathrm{CI}=0.28-0.67)$.

\section{Discussion}

Here, the author presents a review providing a brief and comprehensive summary of recent research using the WCST to assess executive function in patients with TBI. The United States of America has produced most of the studies reviewed, yet they represent research from 17 different countries, from all continents. Worldwide, TBI is recognized as a health priority, given its related global burden (estimated in 2016 as 8.1 million years of life lived with disability; YDLs) and an expected increment in its incidence in view of the exponential population growth, population ageing and more frequent use of vehicles [58]. The WCST is not language-based; instructions are simple and oral interaction between the interviewer and the interviewee can be minimal. This is an important feature in applying the WCST across settings with different languages, yet always keeping in mind the need for standardized scores.

Reports from pediatric samples are scarce. This might be due not only to the limited age range compared with adults, but also to the fact that adults are more likely to be exposed to environmental conditions (e.g., traffic collisions, combat injuries) that may lead to a TBI. Moreover, it must be kept in mind that younger children (i.e., infants and toddlers) are also at very high risk of TBI; however, the WCST is not meant for this population, and other available measures should be considered (e.g., the Behavior Rating Inventory of Executive Function-Preschool Version (BREF-P) and the Developmental NEuroPSYchological Assessment (NEPSY)). The WCST has been standardized for people aged from six and a half to 89 years of age. Demographically corrected normative data provides score profiles according to age: 13 standardized scores tables for children/adolescents (6.5 to 20 years old) and 60 standardized scores tables for adults ( 21 to 89 years old), which also consider the number of years of education. This does not mean that the WCST is rarely applied to the pediatric population, as it is often used for other clinical conditions which are more common in infants in comparison to TBI, such as attention deficit hyperactivity disorder (ADHD) and autism [59].

The original and most widely used version of the WCST includes 128 cards to match. However, a shortened version presenting only the first deck of 64 cards is available, particularly for assessment situations with time restrictions or when the patient's attention span is compromised, as might be the case with elderly [60]. There is also the Modified WCST (M-WCST), a shorter, simpler and less ambiguous version that includes two sets of 24 cards. The M-WCST lacks response cards which share more than one feature with the stimulus cards, the interviewee's first response sets the category criteria, and it estimates perseverative errors differently [61]. More recently, computerized versions have become available, which have the advantages of a more efficient use of resources, improving reliability by equal assessments, and decreasing errors in test presentation, response recording and scoring. This could be very useful for research purposes, particularly when recruiting big samples. Yet, scores from the computerized versions do not seem quite equal to those of manual versions, and new norms for computer versions still need to be established [62].

As an instrument to assess executive function in TBI, the WCST scores have served different purposes according to the studies' designs. In most cases, scores were included as an index of the TBI participants' clinical status, in observational studies with a single case, case series or comparison between groups. Results from these studies helped to gather evidence of the sensitivity (potential to detect those with executive dysfunction) and specificity (potential to exclude those with no executive dysfunction) of the WCST, being essential features of diagnostic instruments. Although for 
research purposes, using the WCST scores as an index of executive dysfunction might be practical when assessing an individual in clinical practice, relying on a single indicator might lead to invalid conclusions. The WCST should be part of a larger and comprehensive neuropsychological battery, and its results should be interpreted along with information from different sources, such as interviews with the patient and relatives, observations and behavioral checklists. Evidence has shown that the capacity of performance-based executive measures, such as the WCST, to predict a patient's ability to function adaptively in daily life after TBI is variable. Patients with compromised executive function can perform well on tests of executive functioning, but demonstrate real-world behavioral disturbances with a reduction of autonomy. Thus, clinicians and researchers must consider the ecological validity of the selected measures and complement them with behavioral data from other sources Kibby and colleagues [63], in testing the ecological validity of the WCST, found that perseverative responses did not significantly correlate with level of job performance, yet it did predict occupational status (from manual labor to higher-level positions). On their part, Pezzuti and colleagues [64] constructed and validated an ecological version of the WCST aimed at the elderly, that was found to be more discriminating and to have more advantages than the traditional versions. The ecological value of the WCST for discriminating functional outcomes, rather than just evidencing the severity of the injury or the presence of a condition, comes forward as a topic worthy of further research.

Randomized control trials used the WCST scores as an outcome variable when testing the effectiveness of a medical treatment (e.g., sertraline [54], growth hormone therapy [52]) or a rehabilitation program (e.g., CogSmart [50,51]; STEP [53]; neuro-feedback [55], vocational problem-solving [56]). The scores obtained before group allocation and treatment, as in the case of descriptive studies, might be useful to evidence the WCST's sensitivity and specificity.

Once the person completes the WCST, all scores can be calculated, yet the studies only reported one or a few of them. Perseverative errors were the scores most often reported. A perseverative response occurs when the interviewee matches a card using the same criterion (color, form or number) used in the immediate previous match, regardless of the response being correct or not. Thus, perseverative errors refer to the number of perseverative responses that were not correct; i.e., the response did not match the valid criterion in turn. Perseverative errors index an incapacity to inhibit a learned response despite knowing from feedback that the response is incorrect. As a measure of executive function, we expect that the greater the dysfunction, the higher the score in perseverative errors. The reported results seem to agree with this, yet the diversity in samples prevents valid comparisons to decide whether there is a significant association between TBI severity and executive dysfunction. Another often-reported score is the number of categories completed; that is, the number (0 to 6) of categories with a sequence of 10 consecutive correct matches to the criterion in turn. Once the subject completes a category, the sorting criterion changes. The test ends when the person completes all six categories or after he/she sorts all the stimulus cards. The ability for completing categories represents the person's capacity to promptly identify the sorting criterion and persevere in providing the correct responses. In some cases, the studies reported that patients with TBI achieved the highest score, while in other cases their scores were not significantly low, and even not so different from those of the controls. This may suggest that patients with TBI have a good ability to figure out the sorting criterion, properly adapting their responses from feedback, despite having difficulties in promptly shifting the criterion, as higher scores in perseverative errors suggest. Raw scores from the interview can be transformed to $\mathrm{T}$ scores and percentile scores, which would be very useful for research and clinical purposes, respectively. It would be ideal if all WCST scores were available from the manuscripts, so that further analyses with data across studies could be made, providing a valid insight into the executive function profile of patients with TBI.

The only author performed the bibliographical search, data collection and analyses, which may be a source of bias. In addition, due to language limitations, four manuscripts that might be relevant to the study's objective (two in Chinese, one in French and one in Turkish) could not be included. 


\section{Conclusions}

This brief review of recent research on the use of the WCST to assess executive function in patients with TBI showed that interest in the topic is worldwide and has been mainly focused on adult populations. Although shorter and/or computerized versions are available, the original WCST with 128 cards is still the most often used. The WCST is a useful tool for research and clinical purposes, yet a common practice is to report only one or a few of the possible scores, which prevents further valid comparisons across studies.

Funding: The Hospital Regional de Alta Especialidad de la Península of Yucatán supported this work by covering the Article Processing Charges.

Acknowledgments: The author thanks Azalia Avila-Nava for their collaboration as a rater in the assessment of the quality of randomized control trials.

Conflicts of Interest: The author declares no conflict of interest.

Availability of Data and Material: The dataset generated and/or analyzed during the current study is available from the corresponding author on reasonable request. 


\section{Appendix A}

Table A1. Assessment of the quality of the randomized control trials with the CASP (Critical Appraisal Skills Programme) checklist.

\begin{tabular}{|c|c|c|c|c|c|c|c|c|c|c|c|c|c|c|}
\hline \multirow[t]{2}{*}{ Reference } & \multicolumn{2}{|c|}{ [50] } & \multicolumn{2}{|c|}{ [51] } & \multicolumn{2}{|c|}{ [52] } & \multicolumn{2}{|c|}{ [53] } & \multicolumn{2}{|c|}{ [54] } & \multicolumn{2}{|c|}{ [55] } & \multicolumn{2}{|c|}{ [56] } \\
\hline & $\begin{array}{c}\text { Rater } \\
1\end{array}$ & $\begin{array}{c}\text { Rater } \\
2\end{array}$ & $\begin{array}{c}\text { Rater } \\
1\end{array}$ & $\begin{array}{c}\text { Rater } \\
2\end{array}$ & $\begin{array}{c}\text { Rater } \\
1\end{array}$ & $\begin{array}{c}\text { Rater } \\
2\end{array}$ & $\begin{array}{c}\text { Rater } \\
1\end{array}$ & $\begin{array}{c}\text { Rater } \\
2\end{array}$ & $\begin{array}{c}\text { Rater } \\
1\end{array}$ & $\begin{array}{c}\text { Rater } \\
2\end{array}$ & $\begin{array}{c}\text { Rater } \\
1\end{array}$ & $\begin{array}{c}\text { Rater } \\
2\end{array}$ & $\begin{array}{c}\text { Rater } \\
1\end{array}$ & $\begin{array}{c}\text { Rater } \\
2\end{array}$ \\
\hline 1. Did the trial address a clearly focused issue? & $\checkmark$ & $\checkmark$ & $\checkmark$ & $\checkmark$ & $\checkmark$ & $\checkmark$ & $\checkmark$ & $\checkmark$ & $\checkmark$ & $\checkmark$ & $\checkmark$ & $\checkmark$ & $\checkmark$ & $\checkmark$ \\
\hline $\begin{array}{l}\text { 2. Was the assignment of patients to treatments } \\
\text { randomised? }\end{array}$ & $\checkmark$ & $\checkmark$ & $\checkmark$ & $\checkmark$ & $\checkmark$ & $\checkmark$ & $\checkmark$ & $\checkmark$ & $\checkmark$ & $\checkmark$ & $\checkmark$ & $\checkmark$ & $\checkmark$ & $\checkmark$ \\
\hline $\begin{array}{l}\text { 3. Were all of the patients who entered the trial } \\
\text { properly accounted for at its conclusion? }\end{array}$ & $\checkmark$ & $\mathrm{x}$ & $\checkmark$ & $\checkmark$ & $\checkmark$ & $\mathrm{x}$ & $\checkmark$ & $\mathrm{x}$ & $\checkmark$ & $\mathrm{x}$ & $\checkmark$ & $\checkmark$ & $\checkmark$ & $\mathrm{x}$ \\
\hline $\begin{array}{l}\text { 4. Were patients, health workers and study } \\
\text { personnel 'blind' to treatment? }\end{array}$ & $\mathrm{x}$ & $?$ & $\mathrm{x}$ & $?$ & $\checkmark$ & $\checkmark$ & $\mathrm{x}$ & $?$ & $\checkmark$ & $\checkmark$ & $?$ & $?$ & $\mathrm{x}$ & $?$ \\
\hline 5. Were the groups similar at the start of the trial? & $\checkmark$ & $\mathrm{x}$ & $\checkmark$ & $\mathrm{x}$ & $\checkmark$ & $\mathrm{x}$ & $\checkmark$ & $\mathrm{x}$ & $\checkmark$ & $\checkmark$ & $\checkmark$ & $\mathrm{x}$ & ? & $\mathrm{x}$ \\
\hline $\begin{array}{l}\text { 6. Aside from the experimental intervention, were } \\
\text { the groups treated equally? }\end{array}$ & $\checkmark$ & $\checkmark$ & $\checkmark$ & $\checkmark$ & $\checkmark$ & $\checkmark$ & $\checkmark$ & $\checkmark$ & $\checkmark$ & $\checkmark$ & $\checkmark$ & $\checkmark$ & $\checkmark$ & $\checkmark$ \\
\hline $\begin{array}{l}\text { *Was the estimated treatment effect adequately } \\
\text { reported? }\end{array}$ & $\checkmark$ & $\checkmark$ & $\checkmark$ & $\checkmark$ & $\checkmark$ & $\checkmark$ & $\checkmark$ & $\checkmark$ & $\checkmark$ & $\checkmark$ & $\checkmark$ & $\checkmark$ & $\checkmark$ & $\checkmark$ \\
\hline $\begin{array}{l}\text { 9. Can the results be applied to the local population, } \\
\text { or in your context? }\end{array}$ & $\checkmark$ & $x$ & $\checkmark$ & $x$ & $\checkmark$ & $\checkmark$ & $\checkmark$ & $\checkmark$ & $\checkmark$ & $\checkmark$ & $x$ & $\checkmark$ & $x$ & $\checkmark$ \\
\hline $\begin{array}{l}\text { 10. Were all clinically important outcomes } \\
\text { considered? }\end{array}$ & $\checkmark$ & $\checkmark$ & $\checkmark$ & $\checkmark$ & $\checkmark$ & $\checkmark$ & $\checkmark$ & $\checkmark$ & $\checkmark$ & $\checkmark$ & $\checkmark$ & $\checkmark$ & $\checkmark$ & $\checkmark$ \\
\hline 11. Are the benefits worth the harms and costs? & $\checkmark$ & $\checkmark$ & $\checkmark$ & $\mathrm{x}$ & $\checkmark$ & $\checkmark$ & $\checkmark$ & $\checkmark$ & $\checkmark$ & $\mathrm{x}$ & $\checkmark$ & $\checkmark$ & $\checkmark$ & $\checkmark$ \\
\hline
\end{tabular}

The original CASP checklist includes item 7 (How large was the treatment effect?) and item 8 (How precise was the estimate of the treatment effect?). These items were substituted by item

*Was the estimated treatment effect adequately reported? $\checkmark$ : Yes; $x$ : No, ?: Can't tell. 


\section{References}

1. Dewan, M.C.; Rattani, A.; Gupta, S.; Baticulon, R.E.; Hung, Y.-C.; Punchak, M.; Agrawal, A.; Adeleye, A.O.; Shrime, M.G.; Rubiano, A.M.; et al. Estimating the global incidence of traumatic brain injury. J. Neurosurg. 2019, 130, 1080-1097. [CrossRef]

2. Baxendale, S.; Heaney, D.; Rugg-Gunn, F.; Friedland, D. Neuropsychological outcomes following traumatic brain injury. Pr. Neurol. 2019, 19, 476-482. [CrossRef]

3. Haller, C.S.; Walder, B. Severe traumatic brain injury in high-income countries. Swiss Arch. Neurol Psychiatry 2015, 166, 114-119.

4. Cristofori, I.; Grafman, J. Executive Functions After Traumatic Brain Injury. Exec. Funct. Health Dis. 2017, 2017, 421-443. [CrossRef]

5. Azouvi, P.; Arnould, A.; Dromer, E.; Vallat-Azouvi, C. Neuropsychology of traumatic brain injury: An expert overview. Rev. Neurol. 2017, 173, 461-472. [CrossRef] [PubMed]

6. The Brain Injury Association. Executive Dysfunction after Brain Injury. 2020. Available online: https: //www.headway.org.uk/media/2801/executive-dysfunction-after-brain-injury-factsheet.pdf (accessed on 5 May 2020).

7. Podell, K.; Gifford, K.; Bougakov, D.; Goldberg, E. Neuropsychological Assessment in Traumatic Brain Injury. Psychiatr. Clin. North Am. 2010, 33, 855-876. [CrossRef] [PubMed]

8. Laxe, S.; Tomás, E.C.; Monsalvez, B.C. Instrumentos de medida más frecuentemente empleados en la valoración del traumatismo craneoencefálico. Rehabilitación 2014, 48, 175-181. [CrossRef]

9. Nyhus, E.; Barceló, F. The Wisconsin Card Sorting Test and the cognitive assessment of prefrontal executive functions: A critical update. Brain Cogn. 2009, 71, 437-451. [CrossRef]

10. Kong, A.P.-H.; Abutalebi, J.; Lam, K.S.-Y.; Weekes, B. Executive and Language Control in the Multilingual Brain. Behav. Neurol. 2014, 2014, 527951. [CrossRef]

11. Kwak, E.H.; Wi, S.; Kim, M.; Pyo, S.; Shin, Y.-K.; Oh, K.J.; Han, K.; Kim, Y.W.; Cho, S. Factors affecting cognition and emotion in patients with traumatic brain injury. NeuroRehabilitation 2020, 46, 369-379. [CrossRef]

12. Ryan, P.B.; Lee-Wilk, T.; Kok, B.C.; Wilk, J.E. Interdisciplinary rehabilitation of mild TBI and PTSD: A case report. Brain Inj. 2011, 25, 1019-1025. [CrossRef] [PubMed]

13. Chaves, C.; Trzesniak, C.; Derenusson, G.N.; Araújo, D.; Wichert-Ana, L.; Machado-De-Sousa, J.P.; Jr, C.G.C.; Nardi, A.E.; Zuardi, A.W.; Crippa, J.A.D.S.; et al. Late-onset social anxiety disorder following traumatic brain injury. Brain Inj. 2012, 26, 882-886. [CrossRef] [PubMed]

14. Van Horn, J.D.; Irimia, A.; Torgerson, C.M.; Bhattrai, A.; Jacokes, Z.; Vespa, P.M. Mild cognitive impairment and structural brain abnormalities in a sexagenarian with a history of childhood traumatic brain injury. J. Neurosci. Res. 2017, 96, 652-660. [CrossRef]

15. Thomas-Antérion, C.; Truche, A.; Sciessere, K.; Extier, C. Spontaneous confabulations and behavioral and cognitive dysexecutive syndrome. Ann. Phys. Rehabil. Med. 2012, 55, 44-52. [CrossRef] [PubMed]

16. Quijano-Martínez, M.C.; Cuervo-Cuesta, M.T. Cognitive impairment after traumatic brain injury. Acta Colomb Psicol. 2011, 14, 71-80.

17. García-Molina, A.; Tormos, J.; Bernabeu, M.; Junqué, C.; Roig-Rovira, T. Do traditional executive measures tell us anything about daily-life functioning after traumatic brain injury in Spanish-speaking individuals? Brain Inj. 2012, 26, 864-874. [CrossRef]

18. Leung, J.; Fereday, S.; Sticpewich, B.; Hanna, J. Extra practice outside therapy sessions to maximize training opportunity during inpatient rehabilitation after traumatic brain injury. Brain Inj. 2018, 32, 915-925. [CrossRef]

19. Krasovsky, T.; Landa, J.; Bar, O.; Jaana, A.-A.; Livny, A.; Tsarfaty, G.; Silberg, T. Functional Plasticity in the Absence of Structural Change. J. Child Neurol. 2017, 32, 505-511. [CrossRef]

20. Barney, S.J.; Allen, D.N.; Thaler, N.S.; Park, B.S.; Strauss, G.P.; Mayfield, J. Neuropsychological and Behavioral Measures of Attention Assess Different Constructs in Children with Traumatic Brain Injury. Clin. Neuropsychol. 2011, 25, 1145-1157. [CrossRef]

21. Formisano, R.; Longo, E.; Azicnuda, E.; Silvestro, D.; D’Ippolito, M.; Truelle, J.-L.; Von Steinbüchel, N.; Von Wild, K.; Wilson, L.; Rigon, J.; et al. Quality of life in persons after traumatic brain injury as self-perceived and as perceived by the caregivers. Neurol. Sci. 2016, 38, 279-286. [CrossRef] 
22. Homaifar, B.Y.; Shura, R.D.; Miskey, H.M.; Yoash-Gantz, R.E.; Rowland, J. The Relationship of Suicidal Ideation to Objective and Subjective Executive Functioning. Mil. Psychol. 2016, 28, 185-191. [CrossRef]

23. Lucas, M.; Buchanan, C. The Tinker Toy Test as a Measure of the Dysexecutive Syndrome in Those from Differing Socio-Economic Backgrounds. South Afr. J. Psychol. 2012, 42, 381-388. [CrossRef]

24. García-Molina, A.; Guitart, M.B.; Roig-Rovira, T. [Traumatic brain injury and daily life: The role of executive function]. Psicothema 2010, 22, 430-435. [PubMed]

25. Karr, J.E.; Rau, H.K.; Shofer, J.B.; Hendrickson, R.C.; Peskind, E.R.; Pagulayan, K.F. Variables associated with subjective cognitive change among Iraq and Afghanistan war Veterans with blast-related mild traumatic brain injury. J. Clin. Exp. Neuropsychol. 2019, 41, 680-693. [CrossRef]

26. Shadli, R.M.; Pieter, M.S.; Yaacob, M.J.; Rashid, F.A. APOE genotype and neuropsychological outcome in mild-to-moderate traumatic brain injury: A pilot study. Brain Inj. 2011, 25, 596-603. [CrossRef] [PubMed]

27. Tunvirachaisakul, C.; Thavichachart, N.; Worakul, P. Executive dysfunction among mild traumatic brain injured patients in Northeastern Thailand. Asian Biomed. 2017, 5, 407-411. [CrossRef]

28. Galetto, V.; Andreetta, S.; Zettin, M.; Marini, A. Patterns of impairment of narrative language in mild traumatic brain injury. J. Neurolinguist. 2013, 26, 649-661. [CrossRef]

29. Zimmermann, N.; Gindri, G.; De Oliveira, C.R.; Fonseca, R.P. Pragmatic and executive functions in traumatic brain injury and right brain damage: An exploratory comparative study. Dement. Neuropsychol. 2011, 5, 337-345. [CrossRef]

30. Hanks, R.A.; Jackson, A.M.; Crisanti, L.K. Predictive validity of a brief outpatient neuropsychological battery in individuals 1-25 years post traumatic brain injury. Clin. Neuropsychol. 2016, 30, 1074-1086. [CrossRef]

31. Kumar, S.; Rao, S.L.; Chandramouli, B.A.; Pillai, S. Reduced contribution of executive functions in impaired working memory performance in mild traumatic brain injury patients. Clin. Neurol. Neurosurg. 2013, 115, 1326-1332. [CrossRef]

32. Dardier, V.; Bernicot, J.; Delanoë, A.; Vanberten, M.; Fayada, C.; Chevignard, M.; Delaye, C.; Laurent-Vannier, A.; Dubois, B. Severe traumatic brain injury, frontal lesions, and social aspects of language use: A study of French-speaking adults. J. Commun. Disord. 2011, 44, 359-378. [CrossRef] [PubMed]

33. Marini, A.; Zettin, M.; Bencich, E.; Bosco, F.M.; Galetto, V. Severity effects on discourse production after TBI. J. Neurolinguist. 2017, 44, 91-106. [CrossRef]

34. Heled, E.; Hoofien, D.; Margalit, D.; Natovich, R.; Agranov, E. The Delis-Kaplan Executive Function System Sorting Test as an evaluative tool for executive functions after severe traumatic brain injury: A comparative study. J. Clin. Exp. Neuropsychol. 2012, 34, 151-159. [CrossRef]

35. Hanks, R.; Millis, S.; Scott, S.; Gattu, R.; O’Hara, N.B.; Haacke, M.; Kou, Z. The relation between cognitive dysfunction and diffusion tensor imaging parameters in traumatic brain injury. Brain Inj. 2018, 33, 355-363. [CrossRef] [PubMed]

36. Bivona, U.; Formisano, R.; De Laurentiis, S.; Accetta, N.; Di Cosimo, M.R.; Massicci, R.; Ciurli, M.P.; Azicnuda, E.; Silvestro, D.; Sabatini, U.; et al. Theory of mind impairment after severe traumatic brain injury and its relationship with caregivers' quality of life. Restor. Neurol. Neurosci. 2015, 33, 335-345. [CrossRef]

37. Strazzer, S.; Rocca, M.A.; Molteni, E.; De Meo, E.; Recla, M.; Valsasina, P.; Arrigoni, F.; Galbiati, S.; Bardoni, A.; Filippi, M. Altered Recruitment of the Attention Network Is Associated with Disability and Cognitive Impairment in Pediatric Patients with Acquired Brain Injury. Neural Plast. 2015, 2015, 104282. [CrossRef] [PubMed]

38. Whiteside, D.; Caraher, K.; E Hahn-Ketter, A.; Gaasedelen, O.; Basso, M.R. Classification accuracy of individual and combined executive functioning embedded performance validity measures in mild traumatic brain injury. Appl. Neuropsychol. Adult 2018, 26, 472-481. [CrossRef]

39. Marini, A.; Zettin, M.; Galetto, V. Cognitive correlates of narrative impairment in moderate traumatic brain injury. Neuropsychol. 2014, 64, 282-288. [CrossRef]

40. Krpan, K.M.; Stuss, D.T.; Anderson, N.D. Coping behaviour following traumatic brain injury: What makes a planner plan and an avoider avoid? Brain Inj. 2011, 25, 989-996. [CrossRef]

41. Crowe, S.F.; Crowe, L.M. Does the presence of posttraumatic anosmia mean that you will be disinhibited? J. Clin. Exp. Neuropsychol. 2013, 35, 298-308. [CrossRef]

42. Ord, J.S.; Greve, K.W.; Bianchini, K.J.; Aguerrevere, L.E. Executive dysfunction in traumatic brain injury: The effects of injury severity and effort on the Wisconsin Card Sorting Test. J. Clin. Exp. Neuropsychol. 2009, 32, 132-140. [CrossRef] [PubMed] 
43. Brenner, L.A.; Bahraini, N.; Homaifar, B.Y.; Monteith, L.L.; Nagamoto, H.; Dorsey-Holliman, B.; Forster, J.E. Executive Functioning and Suicidal Behavior Among Veterans with and Without a History of Traumatic Brain Injury. Arch. Phys. Med. Rehabil. 2015, 96, 1411-1418. [CrossRef] [PubMed]

44. Pereira, N.; Holz, M.; Pereira, A.H.; Bresolin, A.P.; Zimmermann, N.; Fonseca, R.P. Frecuencia de déficits neuropsicológicos post lesión cerebral traumática. Acta Colombiana de Psicología 2016, 19, 105-115. [CrossRef]

45. Ciurli, M.P.; Bivona, U.; Barba, C.; Onder, G.; Silvestro, D.; Azicnuda, E.; Rigon, J.; Formisano, R. Metacognitive unawareness correlates with executive function impairment after severe traumatic brain injury. J. Int. Neuropsychol. Soc. 2010, 16, 360-368. [CrossRef]

46. Zakzanis, K.K.; Grimes, K.M.; Uzzaman, S.; Schmuckler, M.A. Prospection and its relationship to instrumental activities of daily living in patients with mild traumatic brain injury with cognitive impairment. Brain Inj. 2016, 30, 986-992. [CrossRef]

47. Homaifar, B.Y.; Brenner, L.A.; Forster, J.E.; Nagamoto, H. Traumatic brain injury, executive functioning, and suicidal behavior: A brief report. Rehabil. Psychol. 2012, 57, 337-341. [CrossRef]

48. Matsushita, M.; Hosoda, K.; Naitoh, Y.; Yamashita, H.; Kohmura, E. Utility of diffusion tensor imaging in the acute stage of mild to moderate traumatic brain injury for detecting white matter lesions and predicting long-term cognitive function in adults. J. Neurosurg. 2011, 115, 130-139. [CrossRef]

49. Soldatovic-Stajic, B.; Misic-Pavkov, G.; Bozić, K.; Novovic, Z.; Gajic, Z. Neuropsychological and neurophysiological evaluation of cognitive deficits related to the severity of traumatic brain injury. Eur. Rev. Med. Pharmacol. Sci. 2014, 18, 1632-1637.

50. Twamley, E.W.; Jak, A.J.; Delis, D.C.; Bondi, M.W.; Lohr, J.B. Cognitive Symptom Management and Rehabilitation Therapy (CogSMART) for Veterans with traumatic brain injury: Pilot randomized controlled trial. J. Rehabil. Res. Dev. 2014, 51, 59-70. [CrossRef]

51. Twamley, E.W.; Thomas, K.R.; Gregory, A.M.; Jak, A.J.; Bondi, M.W.; Delis, D.C.; Lohr, J.B. CogSMART Compensatory Cognitive Training for Traumatic Brain Injury. J. Head Trauma Rehabil. 2015, 30, 391-401. [CrossRef]

52. High, W.M.; Briones-Galang, M.; Clark, J.A.; Gilkison, C.; Mossberg, K.A.; Zgaljardic, D.J.; Masel, B.E.; Urban, R.J. Effect of Growth Hormone Replacement Therapy on Cognition after Traumatic Brain Injury. J. Neurotrauma 2010, 27, 1565-1575. [CrossRef] [PubMed]

53. Cantor, J.; Ashman, T.; Dams-O'Connor, K.; Dijkers, M.P.; Gordon, W.; Spielman, L.; Tsaousides, T.; Allen, H.; Nguyen, M.; Oswald, J. Evaluation of the Short-Term Executive Plus Intervention for Executive Dysfunction After Traumatic Brain Injury: A Randomized Controlled Trial with Minimization. Arch. Phys. Med. Rehabil. 2014, 95, 1-9.e3. [CrossRef] [PubMed]

54. Baños, J.H.; Novack, T.A.; Brunner, R.; Renfroe, S.; Lin, H.-Y.; Meythaler, J. Impact of Early Administration of Sertraline on Cognitive and Behavioral Recovery in the First Year After Moderate to Severe Traumatic Brain Injury. J. Head Trauma Rehabil. 2010, 25, 357-361. [CrossRef]

55. Reddy, R.P.; Rajeswaran, J.; Devi, B.I.; Kandavel, T. Neurofeedback Training as an Intervention in a Silent Epidemic: An Indian Scenario. J. Neurother. 2013, 17, 213-225. [CrossRef]

56. Man, D.W.K.; Poon, W.S.; Lam, C. The effectiveness of artificial intelligent 3-D virtual reality vocational problem-solving training in enhancing employment opportunities for people with traumatic brain injury. Brain Inj. 2013, 27, 1016-1025. [CrossRef]

57. Critical Appraisal Skills Programme (CASP). CASP Randomised Controlled Trial Checklist. Available online: https://casp-uk.net/wp-content/uploads/2018/01/CASP-Randomised-Controlled-Trial-Checklist-2018. pdf (accessed on 17 August 2020).

58. James, S.L.; Theadom, A.; Ellenbogen, R.G.; Bannick, M.S.; Montjoy-Venning, W.; Lucchesi, L.R.; Abbasi, N.; Abdulkader, R.; Abraha, H.N.; Adsuar, J.C.; et al. Global, regional, and national burden of traumatic brain injury and spinal cord injury, 1990-2016: A systematic analysis for the Global Burden of Disease Study 2016. Lancet Neurol. 2019, 18, 56-87. [CrossRef]

59. Romine, C.B.; Wolfe, M.E.; Homack, S.; George, C.; Lee, D.; Riccio, C.A. Wisconsin Card Sorting Test with children: A meta-analytic study of sensitivity and specificity. Arch. Clin. Neuropsychol. 2004, 19, 1027-1041. [CrossRef]

60. Axelrod, B.N.; Woodard, J.L.; Henry, R.R. Analysis of an abbreviated form of the Wisconsin card sorting test. Clin. Neuropsychol. 1992, 6, 27-31. [CrossRef] 
61. Nelson, H.E. A Modified Card Sorting Test Sensitive to Frontal Lobe Defects. Cortex 1976, 12, $313-324$. [CrossRef]

62. Feldstein, S.N.; Keller, F.R.; Portman, R.E.; Durham, R.L.; Klebe, K.J.; Davis, H.P. A Comparison of Computerized and Standard Versions of the Wisconsin Card Sorting Test. Clin. Neuropsychol. 1999, 13, 303-313. [CrossRef]

63. Kibby, M.Y. Ecological Validity of Neuropsychological Tests Focus on the California Verbal Learning Test and the Wisconsin Card Sorting Test. Arch. Clin. Neuropsychol. 1998, 13, 523-534. [CrossRef] [PubMed]

64. Pezzuti, L.; Mastrantonio, E.; Orsini, A. Construction and validation of an ecological version of the Wisconsin Card Sorting Test applied to an elderly population. Aging Neuropsychol. Cogn. 2013, 20, 567-591. [CrossRef] [PubMed]

(C) 2020 by the author. Licensee MDPI, Basel, Switzerland. This article is an open access article distributed under the terms and conditions of the Creative Commons Attribution (CC BY) license (http://creativecommons.org/licenses/by/4.0/). 